\section{IMAGE UNAVAILABLE FOR COPYRIGHT REASONS}

Lucas: health secretary asked him to stand.

\section{Cancer charity installs former critic as head}

Paris. The financial scandal at France's biggest medical charity, L'Association pour la Recherche contre le Cancer (ARC), took an ironic twist last week when the executive board voted to replace Jacques Crozemarie, its chairman, with the former head of the government agency that had fought for more than a decade to expose its financial irregularities.

The new chairman is Michel Lucas, previously head of the Inspection Générale des Affaires Sociales (IGAS). In 1990, Crozemarie blocked an investigation of ARC by IGAS by winning a court ruling that the agency - which polices public bodies - had no right to investigate private charities. But the preliminary findings of the investigation were leaked to the press, and prompted an investigation by the national audit commission.

The audit commission has now confirmed the main conclusions of the IGAS investigation, namely that only onequarter of the charity's spending went on research (see Nature 379,$103 ; 1995)$. It also found evidence of fraud in the activities of companies associated with the charity, which are being investigated by the public prosecutor.

Lucas agreed to his nomination only a few hours before an extraordinary meeting of the charity's executive board took place last week, and following a personal appeal by Hervé Gaymard, the French secretary of state for health.

In a secret ballot, 17 members of the board voted for Lucas, and 11 against. At the same meeting, 18 voted to accept the conclusions of the auditor's report, and $\mathbf{1 0}$ voted against.

Lucas's first action was to freeze ARC's accounts and to require that all payments received his personal approval. He also promised that the funds allocated to research will increase "rapidly" to one-half of the charity's spending, to clarify the role of ARC's various decision-making bodies, and to establish the "transparency" needed to reestablish the confidence of donors. Lucas also said that ARC would add its name as a plaintiff in the fraud investigations.

Declan Butler

\title{
US court challenge may limit use of data in DNA banks
}

San Francisco. Limitations on the government use of DNA samples stored in genetic databanks are expected to emerge from a court challenge to the collection of such samples by US military authorities .

The case has recently entered an appeals court mediation process in San Francisco. Paul Billings, acting associate professor of medicine at Stanford University, suggests that the outcome could mean that the largest DNA bank in the world will have changed from being entirely unrestricted, to recognizing the dangers associated with the storage of genetic information.

The case began in January last year, when John Mayfield and Joseph Vlacovsky, both members of the US Marine Corps stationed in Hawaii, were asked for a blood sample and a swab taken from the inside of their cheeks for the Department of Defense's DNA Specimen Repository. The military has been collecting such samples since 1992 in order to help identify the remains of those who may be killed in action

In what appears to be the first challenge to an employer's mandatory DNA collection programme, the two individuals refused to provide the required samples, and were court-martialled. Their military case is now on appeal, but meanwhile the two filed a civil suit against the government. Both sides agreed in December to seek mediation through the US Court of Appeals for the Ninth Circuit in San Francisco.

Mayfield and Vlacovsky are objecting to the enforcement of a programme that requires the collection of bodily tissues without their consent, according to Eric Seitz, a civil rights attorney in Honolulu, Hawaii, who is representing the two men. Seitz says that they are particularly concerned that military authorities are not prohibited from using DNA samples for purposes other than the identification of remains.

According to documents that have been lodged with the court, the government set up the database following problems encountered with the identification of individuals who were killed during the 1991 Gulf War. DNA analysis of remains proved more useful than fingerprint or dental records. But it required intrusion into the privacy of family members in order to collect blood samples, and in at least one case raised a question of paternity.

According to Lieutenant Colonel Victor Weedn, the programme manager of the registry, a DNA bank of all those who are in active service is the logical solution, and so far, the bank has collected more than a million samples.

The databank stores the dried blood samples on vacuum-sealed cards placed inside a metal-foil pouch, and the oral swabs in a vial of isopropanol. Both are kept in a secure building, and are available only for limited uses, with access restricted to the resulting information.

The samples can at present be made available for other DNA profile analyses through a formal request to the Assistant Secretary of Defense for Health Affairs, although Weedn says that he knows of no such request having been made or approved so far.

Seitz says that the two men are not trying to shut down the databank; they merely want the collection of samples to be voluntary, and for procedures to ensure that the material can be used only to identify remains. They also believe that samples should be returned or destroyed when an individual has left the military.

According to Weedn, however, the military plans to keep samples from individuals for 75 years before destroying them. This, he says, is because it may take many years to identify remains; in fact, some are still being identified from the Second World War, Korea and Vietnam. He also claims that it would be too time-consuming and costly to return the material to the 200,000 or so members discharged from the military each year.

But Seitz says that his clients remain worried, and would be far less concerned if the whole process were to be based on a process that required the informed consent of participants. He cites various historical examples in which genetics knowledge has been mishandled by the military, such as its use during the mid-1970s to exclude applicants with sickle-cell trait from the Air Force Academy and to disqualify them from aviation and flight crew training in any military department.

Seitz points out that genetic data can be used to analyse predisposition to illnesses, and may be correlated with behavioural characteristics and sexual orientation. "It's too dangerous and explosive of an area for the government to engage in without limitations," he says.

But in documents that have been filed with the San Francisco court, the Marine Corps claims that the plaintiffs have misinterpreted the scope and operation of the DNA bank. It also asserts that all service members have implied their consent to such a programme through their voluntary enlistment, citing previous civil court rulings that military personnel are entitled to less privacy than other citizens, and referring to courts that have upheld the mandatory collection of DNA samples from convicted criminals.

Sally Lehrman 